\title{
THE MYTH OF ALLAHABAD
}

\author{
Muhammad Moiz Khan \\ Erum Ali Warduk ${ }^{* *}$
}

\begin{abstract}
Since the creation of Pakistan the foundation of the Idea of Pakistan has been a matter of academic and political debate. There is a difference between the two spheres. The academic debate allows a room to discuss popular and unpopular ideas and respect the contrary views. The ideology of Pakistan, political system of Pakistan and the constitution of Pakistan have always been discussed and debated amongst scholars. The purpose of this research is to explore the famous presidential address of Allama Iqbal at the annual session of Muslim League in 1930. There are many perceptions about the address delivered by Iqbal, such as he demanded a separate homeland for Muslims of India or not. This research will explore the facts of Iqbal's speech of Allahabad and will attempt to do justice to his words which have been misinterpreted by some spheres.
\end{abstract}

Keywords: Allama Iqbal, Allahabad, Muslim League, independence, autonomy

\section{Introduction}

History is an important aspect of any society. It is necessary for any society to know and understand history of its area, people, evolution and culture. Without acknowledging the past, societies cannot learn from it and thus cannot progress. There are many areas inthe history of Pakistan and the freedom movement for Pakistan where history has been mistreated or misrepresented. There are two main reasons for these trends, first; not all the people writing about the past are properly trained to write about it and secondly they deliberately avoided the more obvious interpretation of events.

\begin{abstract}
History cannot be separated from facts, and depends entirely on reality; and thus the philosophy of history, as it is the spirit or idea of history must be deduced from real historical events, from the faithful record and lively narration of facts -- it must be the pure emanation of the great whole -- the one connected whole of history. And for the right understanding of this connection a clear arrangement is an essential condition and an important aid. ${ }^{1}$
\end{abstract}

The annual session of All India Muslim League was held in Allahabad on December 2930, 1930. This was a very important session because it took place after Nehru Report, Simon Commission, Fourteen Points of Jinnah and All India Muslim Conference. The constitutional solution to the communal problem of India wasthe main theme of 1930's politics. Muslims were putting forward various proposals and demands in front of British and Congress which would give them more space in the social, economic and

\footnotetext{
*Muhammad Moiz Khan, Ph.D., Assistant Professor, Department of History, University of Karachi

${ }^{* *}$ Erum Ali Warduk, Teaching Assistant, Department of History, University of Karachi

${ }^{1}$ Frederick Von Schlegel, The Philosophy of History (New York: D. Appleton \& Co., 1841), 85
} 
political spheres of India. The golden words delivered by Jinnah in 1928 after the Nehru Report was "this is parting of the ways"2. In Indian politics the time from 1913 till 1928 was dominated by Hindu Muslim unity and joint efforts againstBritish. All the major events like Lucknow Pact 1916, Khilafat Movement 1919, AllParties Conference 1928 etc. indicate the same. After parting of the ways the gulf between Muslim League and Congress widened with time and Muslim League was searching in various dimensions to achieve the destination of protection of rights for Muslims.

The decade of 1920's was not so good for the politics of Muslim League. There were many ups and downs faced by the political party and split over different issues surfaced. In this environment of frustration Dr. Muhammad Iqbal was asked to deliver the presidential address in the $21^{\text {st }}$ session of Muslim League in Allahabad. Considerable number of Muslim leadership was in England for attending First Round Table Conference which started on November 12, 1930 and ended on January 19, 1931 ${ }^{3}$.Dr. Iqbal, a man of many traits and ideas was absorbed by the communal issues of India. He was a poet, a philosopher, a writer and a politician. He designed a very well prepared speech for the session. He was trying to address the issues Muslims in India were facing and also to propose plausible solution that could be acceptable to all parties. The address was written and delivered in English but for the consumption of most of the audience it was later explained in Urdu. "Mr. Muhammad Yakub, General Secretary of the Muslim League, explained the substance of the address in Urdu for the benefit of those who did not have sufficient knowledge of English". ${ }^{4}$

\section{Literature Review}

S.M. Burke and SalimAl-Din Qureshi in their book, The British Raj in India have tried to clarify the issue in these words:

....read as a whole, the text makes it quite clear that what Iqbal was proposing at that stage was the grouping of the Muslim majority provinces of north-west India into a single province within an India in which 'the Central Federal State' would exercise 'only those powers which 'the expressly vested in it by the free consent of the federal states'.

A renounced scholar K.K. Aziz in his book Murder of History has also pointed out that Allama Iqbal never meant a separate country for Muslims. This book was an effort by the author to highlight the mistakes we make while framing and writing our textbooks for schools and colleges. He has pointed out several factual errors in textbooks of all provinces of Pakistan. One such instance is, "Iqbal was the first to present to the nation the idea of Pakistan. In 1930 he demanded that an independent state should be created in

\footnotetext{
${ }^{2}$ See, Hector Bolitho, Jinnah: Creator of Pakistan (London: John Murray, 1954), 95 ${ }^{3}$ See, Indian Round Table Conference: $12^{\text {th }}$ November, 1930-19 $9^{\text {th }}$ January, 1931 (Calcutta: Govt. of India, 1931)

${ }^{4}$ Syed SharifuddinPirzada, Foundations of Pakistan: All-India Muslim League Documents: 1906-1947, Vol:II, 1924-1947( Karachi: National publishing House, 1970), 153-154

${ }^{5}$ S.M. Burke, British Raj in India (Karachi: Oxford University Press, 1997)
} 
all the areas of South Asia where the Muslims were in a majority." (MuashratiUlum, Sindh Textbook Board, Jamshoro, $1^{\text {st }}$ ed. 1989, p. 8$)^{6}$.

Black Swan press published a research article in 2009 "People, Place and Power: Australia and the Asia Pacific" which was edited by Dawn Bennett, Jaya Earnest and MiyumeTanji. This article stated that, "Iqbal in 1930 was not demanding a separate sovereign nation state for the Muslims or partition of India, but recognition of a confederate nation".

R. J. Moore opines, “As president of the League in 1930 the philosopher-poet of Lahore, Sir Muhammad Iqbal, had called for the amalgamation of the four north-western provinces, less some non-Muslim districts, into 'a Muslim India within India'. As the religious units of India had never been inclined to sacrifice their individualities in a larger whole 'the unity of an Indian nation must be sought, not in negation, but in mutual harmony and co-operation'. The 'effective principle of co-operation' in India was the recognition of 'homelands' in which the Muslim might enjoy 'full and free development on the lines of his own culture and tradition",,7.

\section{The misconception}

History of Pakistan and the movement which lead to the independence of it is a popular theme for Pakistanis. There have been many books written on the struggle for Pakistan and the personalities involved in it. However there are many versions of some facts and ideas. Allahabad Address by Dr. Allama Iqbal is one such event. First there are scholars who believe that Allama Iqbal presented the demand of Pakistan in this address by chalking out the areas which later became Pakistan. Secondly other scholars believe that Dr. Iqbal was not asking for separate homeland for Muslims of India at the time, however, all he wanted to demand was autonomy in Muslim majority areas and freedom to develop themselves like other communities of India.

Then there is a concept proposed by various scholars that Dr. Iqbal had the dream of Pakistan. They say that the areas which Dr. Iqbal mentioned in his speech later became independent Pakistan so it can be interpreted as a dream. However, if it can be considered as a dream then Pakistan in 1947 was not the exact realization of this dream, because in 1947 East Bengal was the lager part of Pakistan in term of population and it was not even hinted in Dr. Iqbal's Address of 1930. This is a vague idea attracting the imagination of layman.

\section{Reasons for the misconception}

History as a discipline in Pakistan has been not given its true place in comparison to other disciplines. It is the most underrated disciplines in Pakistan and as result students do not give importance to history. As other underdeveloped and developing countries in

\footnotetext{
${ }^{6}$ K.K. Aziz, The Murder of History: A Critique of History Textbooks used in Pakistan, (Lahore: Vanguard, 1993), 18.

${ }^{7}$ R. J. Moore, "Jinnah and the Pakistan Demand," Modern Asian Studies, Vol. 17, No. 4 (1983) http://www.jstor.org/stable/312235Accessed: July 11, 2013.
} 
Pakistan too much importance is given to professional and vocational subjects. The textbook drafters and planners do not play the desired attention towards the contents they include in books. Historical references are not crosschecked after mentioning them. In some cases there are more than one version of any historical fact that needs to be verified and alongside it the others should also be mentioned to clarify the issue so that the reader and in case of textbook student do not get confused about it when they come to know the other versions of a particular fact.

In a TV interview in October 2016 Ahsan Iqbal, federal minister of planning and development stated that after $18^{\text {th }}$ amendment provinces were giventhe responsibility to prepare curriculum books. Later all provinces surrendered their particular autonomy and agreed to the central curriculum authority in Islamabad under federal government because of their incapacity. Now the federal government is mustering resources from all over Pakistan to accomplish the task.

One such example is of the date of the birth of Muhammad Ali Jinnah. There are two dates, one more popular $25^{\text {th }}$ December and the other one is $20^{\text {th }}$ October. "The date is uncertain: in the register of his school, in Karachi, the day is recorded as October 20, 1875; but Jinnah always said that he had been born on Christmas Day a Sunday in 1876." ${ }^{8}$ The researcher have personally seen the register in Sindh Archives, Karachi in 2009. It is still available there.

\section{The Address}

As the president of the League in 1930, the philosopher-poet of Sialkot, Sir Muhammad Iqbal, had called for the amalgamation of the four north-western provinces, less some non-Muslim districts, into 'a Muslim India within India'. As religious groups of India had never been inclined to sacrifice their individualities in a larger whole 'the unity of an Indian nation must be sought, not in negation, but in mutual harmony and cooperation'. The 'effective principle of co-operation' in India was the recognition of 'homelands' in which the Muslim might enjoy 'full and free development on the lines of his own culture and tradition"9.

The part, which has been misunderstood, misinterpreted, misquoted and propagated without responsibility was the one in which Iqbal proposed an autonomous Northwest province for Muslims. The idea that Iqbal asked for an independent country in the Allahabad Address is nothing short of a myth. There are many evidences to enforce and substantiate the idea that Iqbal never mentioned and wanted a "separate independent country for Muslims", of the Subcontinent at least as early as 1930.

Addressing the Muslim League session in 1930, he said that the Muslim of India would not spare the greatest sacrifices for the freedom of their country if their right to autonomous growth within the country under their own traditions and cultures was conceded. Concretely, Iqbal suggested reorganisation of the

\footnotetext{
${ }^{8}$ Hector Bolitho, Jinnah: Creator of Pakistan (London: Jhon Murray, 1954), 3

${ }^{9}$ Moore, op.cit"Jinnah and the Pakistan Demand,"
} 
country on the basis of language, race, history, religion and economic interests within the federal system with maximum autonomy for the state. ${ }^{10}$

There are different perceptions about the address. First and the most popular, as has been mentioned, is that he demanded a separate independent country out of India. The other vague interpretation is that he presented the idea of Pakistan. There is a difference of opinion that the areas Iqbal wanted to become autonomous within India later became Pakistan. So with this connection it would be safe to say that he presented the idea of Pakistan. The later version is difficult to ignore compared to the earlier one and make more sense.

Before pondering upon the address itself we need to understand the political situation of contemporary India. The last constitution implemented in India was Mont-Ferd Reforms in 1919. One important feature of the constitutional reforms was, it would be reassessed for any necessary changes according to the requirements of the time regarding responsible government with in ten years of its implementation. However the Secretary of State Lord Birkenhead had other opinion. On December 4, 1924 he wrote to Lord Readings, "to me it is frankly inconceivable that India will ever fit for Dominion Self Government" ${ }^{\text {"11 }}$. In 1928 he gave challenge to Indians to come to produce their own scheme of constitution rather than making destructive criticism on government efforts ${ }^{12}$.

In anticipation Muslim League and Congress had already initiated the task in 1927, when Congress invited proposals from minorities towards addressing their concerns according to their desires. Muslim League presented Delhi Proposals on March 20, 1927 which were responded by Congress in May 1927 along with one dissention on four points presented by the League. The proposals surrendered separate electorates against the demand of one third seats in the central legislature for Muslims. Later in 1928 Congress called All Parties Conference to respond to the challenge posed by British to develop a constitution which would be acceptable to all.

This conference was attended by all political entities along with Muslim League with high hopes. The result of this conference was the Nehru Report. The report strikingly negated the principles of provincial autonomy and favoured strong centre ${ }^{13}$. Muslim League objected on it along with minority Hindus ${ }^{14}$. Jinnah offered three amendments in the report which were quashed by Congress. The report demanded immediate Dominion Status from British however British were of the opinion that India was not ready for it.

\footnotetext{
${ }^{10}$ BalrajPuri, "Iqbal and Idea of Pakistan", Economic and Political Weekly, vol.38, no.5 (Feb 1-7, 2003) available at: http://www.jstor.org/stable/4413166?seq=1\#page_scan_tab_contents.Accessed July 18, 2013

${ }^{11}$ Bolitho, Creator of Pakistan, 93

${ }^{12}$ Ibid., 93

${ }^{13}$ The report recommended, residuary powers will lie with central government and the upper house senate would be elected on the basis of population. Both these points negate the ideals of Federation.

${ }^{14}$ Out of the eleven initial members of the committee Shoaib Qureshi and Pradhan refused to accept the report on the pretext that it does not safeguard minorities.
} 
Jawaharlal Nehru was elected as the president of Congress in 1929 and he demanded 'Puransawaraj' 15 from British in December 1929 in Lahore. Congress even celebrated January 26, 1930 as Independence Day ${ }^{16}$.

Considering the political activism, ethnic frictions and constitutional deadlocks British Prime Minister, Ramsay McDonald, invited all political parties to England for Round Table Conferences to discuss and resolve constraints and aspirations of minorities towards achieving a constitution. All major players including Jinnah had gone to England for the meetings which started on November 12, 1930 ${ }^{17}$. Congress had abstained from the conference due to the boycott in favour of their demand of 'Puransawaraj'.

It was under these circumstances Allama Iqbal was invited to present the presidential address of the annual session of Muslim League. The session was marked by the absence of major leadership. It was attended by few people. His address had nothing new if we look at it in comparison to the previous demands by Muslim League such as Delhi Proposals, 14 points of Jinnah and Delhi Muslim Conference. He presented almost same things with new dimensions added to them. However it was a lengthy document prepared with care and displayed his genius in arguing his position.

There are many different reasons behind the birth of the 'Myth'. The famous words of Iqbal, which reify the myth, are, "I would like to see the Punjab, North-West Frontier Province, Sind and Baluchistan amalgamated into a single state" ${ }^{\text {"T }}$.These words alone do not and cannot portray the real picture. This sentence even does not signal towards an independent country. Any text cannot be understood in isolation and needs to be seen in totality.

The term 'state' has been misunderstood and hence sole creator of the myth. The term 'state' has various meanings. On one hand it does mean an independent country but it also means a constituent unit of a country of an organized political community forming part of a country: like state of Victoria and Western Australia, the southern states of the United States, as described in Oxford Dictionary. The Merriam Webster dictionary explains the same term as, "one of the constituent units of a nation having a federal government (the fifty states): The United States of America". In India even today, word 'state' is used for federating units e.g. State of Punjab, State of Bengal.

Another misconception arises when Allama goes further and says, "Self-government within the British Empire, or without the British Empire, the formation of a consolidated North-West India, 19 . The supporters of the view that he demanded independent country say that Allama in these lines is stating that, "with or without the British Empire",which indicates the fact that during the British rule or after independence of India. It was specifically said because on December 1929 Congress had demanded independence.

${ }^{15}$ It's a Hindi word which means 'Full Independence'.

${ }^{16}$ Jawaharlal Nehru, Toward Freedom (New York: The John Day Company, 1941), 150

${ }^{17}$ See, R. Coupland, The Indian Problem: Report on the Constitutional Problems in India Vol: I (New York: Oxford, 1944), 113

${ }^{18}$ Allama Iqbal, Allahabad Address, 3 (b)

${ }^{19}$ Ibid., 3(b) 
A thorough study of the text of Iqbal's Allahabad address shows that he used the word state in place of province. Province is a more commonly used word to describe constituting parts of a federal state and comparatively easy to understand that it does not mean an independent country. The use of the word State in place of province was debated by his contemporaries and Iqbalclarified that he meant a unit.

Iqbal had always been proponent of Muslim nationalism along with Indian nationalism. His poetic works indicate his affection for India. Until now the most popular patriotic song for over a century was written by Iqbal. In fact his poetry reinforces his idea of great unified India. He writes in his Tarana-e-Hindi in 1904,

$$
\begin{aligned}
& \text { Sārejahān se acchā, Hindositānhhamārāa } \\
& \text { Ham bulbulen hain is kī, yihgulsitān hamārā } \\
& \text { Ghurbat men hon agar ham, rahtāhaidilwațan men } \\
& \text { Samjhowuhīn hamen bhīdil ho jahān hamārā } \\
& \text { Parbat wuh sab se ūncā, hamsāyahāsmān kā } \\
& \text { Wuhsantarīhamārā, wuhpāsbān hamārā } \\
& \text { Godī men kheltīhain is kīhazāron nadiyān } \\
& \text { Gulshanhaijinke dam se ras } \underline{h} k \text {-ijanān hamārā } \\
& \text { Ai āb-irūd-iGangāa! wuh din hain yādtujhko? } \\
& \text { Utrātire kināre jab kārwān hamārāa } \\
& \text { Mažhabnahīn sikhātāāpas men bairrakhnā } \\
& \text { Hindīhain ham, wațanhaiHindositān hamārāa } \\
& \text { Yūnān o-Miṣr o-Rūmā, sab mitga'ejahān se } \\
& \text { Abtakmagarhaibāqī, nāmo-nish han hamārā } \\
& \text { Kuchbāthaikihhastī, mițtīnahīn hamārī } \\
& \text { Sadiyon rahāhaidus } \underline{\text { h }} \text { mandaur-izamān hamārā } \\
& \text { Iqbāl! Koīmaḥramapnānahīn jahān men } \\
& \text { Ma 'lūmkyākisīkodard-inihān hamārāa' }
\end{aligned}
$$

Edward Thompson, a news reporter in England called Iqbal a protagonist of the scheme called Pakistan. Allama took notice of this incident and protested in a letter to him dated $4^{\text {th }}$, March $1934^{20}$. Iqbal further clarified that all he proposed in Allahabad address was a Muslim province within Indian Federation, where Muslim would have full autonomy.

I have just received your review of my book. It is excellent and I am grateful to you for the very things you have said of me. But you have made one mistake which I hasten to point out as I consider it rather serious. You call me a protagonist of the scheme called Pakistan. Now Pakistan is not my scheme. The

${ }^{20}$ See, S.M. Burke, British Raj in India (Karachi: Oxford, 1997) 
one that I suggested in my address is the creation of a Muslim Province-i.e. a province having an overwhelming population of Muslims-- in the North West of India. This new province will be, according to my scheme, a part of the proposed Indian Federation. Pakistan scheme proposes a separate federation of Muslim Provinces directly related to England as a separate dominion. This scheme originated in Cambridge. The author of this scheme believes that we Muslim Round Tablers have sacrificed the Muslim Nation on the altar of Hindu or the so-called Indian Nationalism. ${ }^{21}$

It is a common practice of non-historians that while writing about and commenting on historical events and personalities they do not consult the original text and even if they do they skip the details and focus on any part before constructing an opinion. The speech under discussion is a long one and exhausting for a layman ${ }^{22}$. Secondly the whole speech is not easily available for readers to consult.

Further examination of the text of Allahabad address shows us that Iqbal asked for an autonomous province for Muslims. "Thus, possessing full opportunity of development within the body politic of India, the North-West Indian Muslims will prove the best defenders of India against a foreign invasion, be that invasion one of ideas or of bayonets "23. Here Iqbal has highlighted the importance of Muslim province not only for Muslims of the said region but to the security of India from any foreign invasion. History is an eyewitness to the fact that every foreign invasion has come from NorthWest of India.

Then he further propagates the importance of the Muslim population of this region to India, "Punjab with 56 percent Muslim population supplies 54 percent of the total combatant troops in the Indian Army, and if the 19,000 Gurkhas recruited from the independent state of Nepal are excluded, the Punjab contingent amounts to 62 percent of the whole Indian Army by the North-West Frontier province and Baluchistan. From this you can easily calculate the possibilities of North-West Indian Muslims in regard to the defense of India against foreign aggression ${ }^{24 " .}$. Allama Iqbal in his address, also tried to eliminate the fear of Hindus regarding the creation of Muslim province in these words;

The Right Hon'bleMr.SrinivasaSastri thinks that the Muslim demand for the creation of autonomous Muslim states along the north-west border is actuated by a desire 'to acquire means of exerting pressure in emergencies on the government of India'. I may frankly tell him that the Muslim demand is not actuated by the kind of motive he imputes to us; it is actuated by a genuine desire for free development which is practically impossible under the type of unitary government contemplated by the nationalist Hindu politicians with a view to secure permanent communal dominance in the whole of India". 25

\footnotetext{
${ }^{21}$ Letter to Edward Thompson, March 4, 1934.

${ }^{22}$ It has around 9,400 words.

${ }^{23}$ Allahabad Address, 3 (c)

${ }^{24}$ Ibid, 3(c)

${ }^{25}$ Ibid., 3(c)
} 
Thus it is clear that in view of India's infinite variety in climates, races, languages, creeds and social system, the creation of autonomous States, based on the unity of language, race, history, religion and identity of economic interests, is the only possible way to secure a stable constitutional structure in India. The conception of federation underlying the Simon Report necessitates the abolition of the Central Legislative Assembly as a popular assembly, and makes it an assembly of the representatives of federal states. It further demands a redistribution of territory on the lines which I have indicated. And the Report does recommend both. I give my wholehearted support to this view of the matter, and venture to suggest that the redistribution recommended in the Simon Report must fulfil two conditions. It must precede the introduction of the new constitution, and must be so devised as to finally solve the communal problem. Proper redistribution will make the question of joint and separate electorates automatically disappear from the constitutional controversy of India. It is the present structure of the provinces that is largely responsible for this controversy. ${ }^{26}$

Iqbal was reaffirming the right ofMuslimsto have as much autonomy as possible. He had targeted the idea of Indian Nationalism propagated by Congress. He was opposed to the notion that there are no minorities in India and all the people living in India have singular Indian identity.

Yet Iqbal's call for a Muslim state in north-western India did not envisage a severance of all ties with Hindustan. In contesting their part in relation to the whole of India, Muslims quite as much as other religious groupings were asserting rights to territories based on religiously informed cultural identities. But they were still mainly challenging the congress's right to indivisible sovereignty, not rejecting any sort of identification with India. ${ }^{27}$

In adumbrating a consolidated North Western India Muslim state in his Allahabad (1930) Address, Iqbal, as he put it, was seeking to overcome or nullify the diversity in India's body politic represented by the Muslim penchant to retain their distinct identity and individuality in the subcontinent. In a bid to offer a democratic solution, he sought to salvage "the life of Islam as a cultural force in the country", the major thrust and source of diversity, by "its centralization in a specified territory". He felt that "this centralization of the most living portion of the Muslims of India... will eventually solve the problem of India", arguing that "without the fullest cultural autonomy, and communalism in its better aspect as culture, it will be difficult to create a harmonious nation". That is, the Islamic diversity should be afforded full opportunities for development along its own lines without being thwarted or checkmated by the majoritarian culture and ethos in the rest of the subcontinent. Thus Iqbal stood for an inclusive salad plate matrix as against the congress' assimilative melting pot approach, which shunned recognition and accommodation of non-congress and non-Hindu identities. But this Iqbal's viable panacea for meeting the monumental challenge of Muslim diversity and creating a "harmonious" and integrated Indian nation, with unity

\footnotetext{
${ }^{26}$ Ibid., 4(a)

${ }^{27}$ Ayesha Jalal, "Nation, Reason and Religion: The Punjab's Role in the Partition of India", The G.M. Trevelyan Seminar, University of Cambridge (8 August, 1998), available at:

http://emerald.tufts.edu/ ajalal01/Articles/epw.piece.pdfAccessed November 13, 2014
} 
at the top and diversity at the bottom of India's politico-cultural pyramid in prepartition colonial India, was rejected out of the hand on outrageously flimsy grounds. ${ }^{28}$

\section{Conclusion}

Dr. Allama Iqbal was one of the greatest thinkers of his times. He has served the Muslims of subcontinent more than most of his contemporaries. His ideas and political works served as a path and ray of hope for Muslims of this region in their struggle of rights and self-determination. His address of Allahabad was a fine piece of political thought in which he presented a political solution for the hardships faced by the Muslims. He presented his thought in a way that adjustments may be made in it according to the need and appropriate suggestions from any corner of body politic of India.

The study of contemporary politics has revealed that Muslim League was willing to surrender their primary demand of separate electorates for fixture of one third seats in the Central Legislation Council for Muslims. They presented this idea in March 1927 in Delhi Proposals. The later developments and denial of Congress to adjust Muslim demands resulted into "parting of the ways". Allama Iqbal when asked to deliver the presidential address at the annual session of Muslim League in 1930 drafted a master peace of political importance. He summed up Muslim aspirations by demanding formation of Muslim province which would have full provincial autonomy.

Political developments were taking shape rapidly in those days and Sir Mohammad Iqbal had ushered his opinion to be heard in the Round Table Conference when he firmly demanded Sindh, Punjab, N.W.F.P and Baluchistan did not enjoy status of a province. Sindh and N.W.F.P became separate provinces in the Act of India 1935 and Baluchistan was never made a full province until much after the independence.

He had not presented a full and detailed political structure of India, however he directed towards the plausible solutions that would be acceptable to all. His address had proved to be ambiguous to many who were unable to grasp the actual genius of the idea of Dr. Iqbal. He till his death was a protector of Muslim rights and fighter against suppression. His political legacy contributed in freedom movement in post-Lahore Resolution struggle. His ideas and poetry poured new blood in the political movement led by Jinnah in 1940s which culminated into Pakistan.

\footnotetext{
${ }^{28}$ Sharif al Mujahid, "Finding Balance between Unity and Diversity: A major challenge to Democracy, Governance and National Unity", available at: http://pu.edu.pk/images/journal/studies/PDF-FILES/Artical2_V13_No2_2012.pdf
} 